\title{
Effect of Different Concentration of Seaweed Saps on Quality, Green Fodder and Seed Yields of Berseem (Trifolium alexandrium)
}

\author{
A. K. Jha*, Arti Shrivastava, A. K. Mehta, S. K. Billaiya and N. S. Raghuvanshi
}

Dept. of Agronomy, Jawaharlal Nehru Krishi Vishwa Vidyalaya, Jabalpur, Madhya Pradesh (482 004), India

\section{Article History}

Manuscript No. AR1649

Received in $6^{\text {th }}$ August, 2016

Received in revised form $30^{\text {th }}$ August, 2016

Accepted in final form $21^{\text {st }}$ September, 2016

\section{Correspondence to}

*E-mail: amitagcrewa@rediffmail.com

\section{Keywords}

Seaweed saps, green fodder, quality and seed yield

\begin{abstract}
A field experiment was conducted during rabi seasons 2012 and 2013 at research farm of Department of Agronomy Jawaharlal Nehru Krishi Vishwa-Vidyalaya, Jabalpur, Madhya Pradesh, India. The experiment was laid out in Randomized Block Design in three replications with ten treatments are as follows: $\mathrm{RDF}+2.5 \% \mathrm{~K}$-sap, $\mathrm{RDF}+5 \%$ $\mathrm{K}$ sap, $\mathrm{RDF}+7.5 \% \mathrm{~K}$ sap, RDF+10\% K sap, RDF $+2.5 \% \mathrm{G}$ sap, $\mathrm{RDF}+5 \% \mathrm{G}$ sap, $\mathrm{RDF}+7.5 \% \mathrm{G}$ sap, $\mathrm{RDF}+10 \% \mathrm{G}$ sap, $\mathrm{RDF}+$ water spray, $50 \% \mathrm{RDF}+6.25 \% \mathrm{~K}$ sap. The sowing date of Berseem variety- JB-5 were sown on $17^{\text {th }}$ November, 2012 and $19^{\text {th }}$ November of 2013. The highest GFY and DMY were recorded with the application of RDF with $10 \% \mathrm{G}$ sap ( 613.45 and $\left.83.24 \mathrm{q} \mathrm{ha}^{-1}\right)$ followed by application of RDF $+10 \%$ $\mathrm{K}$ sap (607.35 and $82.01 \mathrm{q} \mathrm{ha}^{-1}$ ), similarly the maximum seed yield and stover yield were recorded with the application of RDF with $10 \% \mathrm{G}$ sap (4.72 and $62.36 \mathrm{q} \mathrm{ha}^{-1}$ ) followed by application of RDF $+10 \% \mathrm{~K}$ sap ( 4.07 and $\left.60.59 \mathrm{q} \mathrm{ha}^{-1}\right)$, respectively due to presence of growth promoting hormones (Auxins, Cytokinins, Gibberellins), trace elements, vitamins, amino acids, antibiotics and micronutrients in these saps. The higher crude protein yield and crude fiber yield were observed under application of $10 \% \mathrm{G} \mathrm{sap}+\mathrm{RDF}$ (11.67 and $15.10 \mathrm{q} \mathrm{ha}^{-1}$ ) followed by $10 \% \mathrm{~K}$ sap+RDF (11.83 and $\left.15.34 \mathrm{q} \mathrm{ha}^{-1}\right)$.
\end{abstract}

\section{Introduction}

The seaweeds resources are intensively used to improve harvest quantity and quality in agriculture and horticulture. The beneficial effects of seaweed products on the cultured plants are well documented. The using of seaweed products improve seeds germination, seedlings development, increase plant tolerance to environmental stresses (Zhang and Ervin, 2008), and enhance plant growth and yield (Kumari et al., 2011; Craigie, 2011). More over seaweeds are used as soil amendment (Gandhiyappan and Perumal, 2001), in pests control (Hong et al., 2007) and plant diseases management (Jayaraj et al., 2008). Liquid extracts obtained from seaweeds have gained importance as foliar sprays and soil drench for many crops including various grasses, cereals, flowers and vegetable species. Also they apply to stimulate seedling germination and rooting. Seaweeds have been used as manure, cattle feed, food for human consumption and as a source of phycocolloids such as agar, alginic acid and carrageenan. Besides their application as Farmyard Manure (FYM), liquid extracts obtained from seaweeds (LSF/SLF) have recently gained importance as foliar sprays for several crops because the extract contains growth promoting hormones (IAA and IBA), cytokinins, trace elements ( $\mathrm{Fe}, \mathrm{Cu}, \mathrm{Zn}, \mathrm{Co}, \mathrm{Mo}, \mathrm{Mn}$, $\mathrm{Ni}$ ), vitamins (Sivasankari, 2006). Seaweed extracts have been reported to stimulate the growth and yield of plants, develop tolerance to environment stress, increase nutrient uptake from soil and enhance antioxidant properties (Rathore, 2009). Recently researchers proved that seaweed fertilizers are better than other fertilizers and are very economical (Sivasangari et al., 2011).

\section{Materials and Methods}

\subsection{Preparation and chemical composition of liquid seaweed} extracts

The algae Kappaphycus sp. and Gracilaria sp. were handpicked from the coastal area of Rameswaram, Tamilnadu (India) in September, 2011. The seaweed were washed with water to remove unwanted impurities and transported to the laboratory at Mandapum, Rameswaram. The seaweed samples were thoroughly washed using tap water and homogenized in a grinder with stainless steel blades at ambient temperature, filtered and stored. The liquid filtrate was taken as $100 \%$ 
concentration of seaweed extract and diluted as the treatments ${ }^{-1}$. The nitrogen $(\mathrm{N})$ content of seaweed extract was determined by taking $20 \mathrm{ml}$ filtrate and oxidized by concentrate sulphuric acid $(10 \mathrm{ml})$ with digestion mixture $\left(\mathrm{K}_{2} \mathrm{SO}_{4}: \mathrm{CuSO}_{4}=5: 1\right)$ heated at $400{ }^{\circ} \mathrm{C}$ for $2 \frac{1}{2} \mathrm{~h}$ as semi-micro Kjeldahl's method. The other nutrient elements were analyzed by inductively coupled plasma-optical emission spectroscopy (ICP-OES) after wet digestion of filtrate $(20 \mathrm{ml})$ with $\mathrm{HNO}_{3}-\mathrm{HClO}_{4}(10: 4)$ diacid mixture $(20 \mathrm{ml})$ and heated at $100{ }^{\circ} \mathrm{C}$ for $1 \mathrm{~h}$ and then temperature raised to $150^{\circ} \mathrm{C}$.

\subsection{Details of the experiment}

A field experiment was conducted during rabi seasons 2012 and 2013 at research farm of department of agronomy, Jawaharlal Nehru Krishi Vishwa Vidyalaya, Jabalpur, Madhya Pradesh, India. The experiment was laid out in Randomized Block Design in three replications with ten treatments are as follows: $\mathrm{RDF}+2.5 \% \mathrm{~K}$ sap,$+ \mathrm{RDF}+5 \% \mathrm{~K}$ sap, $\mathrm{RDF}+7.5 \% \mathrm{~K}$ sap, RDF+10\% K sap, RDF+2.5\% G sap, RDF+5\% G sap, $\mathrm{RDF}+7.5 \% \mathrm{G}$ sap, RDF+10\% G sap, RDF+water spray, 50\% $\mathrm{RDF}+6.25 \% \mathrm{~K}$ sap. Spraying of seaweed saps Kappaphycus sap (K sap) and Gyaciradia Sap (G sap) were done at 30 days, first cutting (at 55 days) and second cutting (at 75 days) of berseem after sowing. Berseem var. JB 5 was sown by broadcast method by using seed rate of $35 \mathrm{~kg} \mathrm{ha}^{-1}$.

The crop was fertilized as the recommended ${ }^{-1}$ dose of 20:60:20 $\mathrm{kg}$ NPK ha-1. The $100 \%$ dose of N, $\mathrm{P}_{2} \mathrm{O}_{5}$ and $\mathrm{K}_{2} \mathrm{O}$ were applied as basal in the form of urea, SSP and MOP, respectively. As per the proposed set up of treatments by company the dose of $\mathrm{K}$ sap and $\mathrm{G}$ sap were applied at the time of cutting in three foliar sprays. After physical maturity berseem were harvested in the month of May. Total seed yield was noted at harvest in $\mathrm{kg}$ plot $^{-1}$.

\section{Results and Discussion}

\subsection{Effect on green fodder yield}

The shoot height was recorded at first, second and third cutting of the besrseem and average shoot height was calculated (Table 1). It observed that the increasing the dose of $K$ sap as well as $\mathrm{G}$ sap increases the average shoot height significantly. The maximum average shoot height was observed under application of RDF with $10 \% \mathrm{G}$ sap (49.49 cm) followed by application of $\mathrm{RDF}+10 \% \mathrm{~K}$ sap $(49.72 \mathrm{~cm})$, while minimum average shoot height was recorded under RDF+water spray $(42.81 \mathrm{~cm}) . \mathrm{L}: \mathrm{S}$ ratio of different treatments was presented in (Table 1). Data revealed that all the combination of $\mathrm{K}$ sap as well as $\mathrm{G}$ sap with recommended dose of fertilizer recorded significantly higher L:S ratio. The maximum L:S ratio was observed with the application of RDF with $10 \% \mathrm{G}$ sap (0.98) followed by application of $\mathrm{RDF}+10 \% \mathrm{~K}$ sap (0.95), while minimum L:S ratio was recorded under $\mathrm{RDF}+$ water spray (0.76). Data revealed that all the combination of $\mathrm{K}$ sap as well as $\mathrm{G}$ sap with recommended dose of fertilizer recorded significantly higher GFY and DMY. The highest GFY and DMY were recorded with the application of RDF with $10 \% \mathrm{G}$ sap (613.45 and 83.24 $\left.\mathrm{q} \mathrm{ha} \mathrm{h}^{-1}\right)$ followed by application of RDF+10\% K sap $(607.35$ and $82.01 \mathrm{q} \mathrm{ha}^{-1}$ ), while the lowest GFY and DMY recorded under RDF+water spray (559.2 5 and $72.49 \mathrm{q} \mathrm{ha}^{-1}$ ). There was an increase in vegetative growth parameters by the application of seaweed extract. This is coincided with those of earlier studies made in Phaseolus vulgaris L. (Kocira et al., 2013).

\subsection{Effect on fodder quality}

The data presented in Table 1 showed that the average crude

Table 1: Effect of different treatments on shoot length, L:S ratio, green fodder yield, dry matte yield, crude protein \%, crude protein yield and crude fiber \% of berseem (Mean of two year 2012 and 2013)

\begin{tabular}{|c|c|c|c|c|c|c|c|c|}
\hline Treatments & $\begin{array}{l}\text { Shoot } \\
\text { length }\end{array}$ & $\begin{array}{l}\mathrm{L}: \mathrm{S} \\
\text { ratio }\end{array}$ & $\begin{array}{c}\text { Green } \\
\text { fodder yield } \\
\left.\qquad(\mathrm{q} \mathrm{ha})^{-1}\right)\end{array}$ & $\begin{array}{l}\text { Dry mat- } \\
\text { ter yield } \\
\left.(\mathrm{q} \mathrm{ha})^{-1}\right)\end{array}$ & $\begin{array}{l}\text { Crude } \\
\text { protein } \\
\%\end{array}$ & $\begin{array}{c}\text { Crudeprotein } \\
\text { yield } \\
\left(\mathrm{q} \mathrm{ha}^{-1}\right)\end{array}$ & $\begin{array}{l}\text { Crude } \\
\text { fiber } \%\end{array}$ & $\begin{array}{l}\text { Crude fiber } \\
\text { yield }\left(\mathrm{q} \mathrm{ha}^{-1}\right)\end{array}$ \\
\hline $\mathrm{RDF}+2.5 \% \mathrm{~K}$ sap & 48.34 & 0.82 & 575.85 & 76.10 & 15.06 & 10.80 & 18.17 & 13.65 \\
\hline $\mathrm{RDF}+5 \% \mathrm{~K}$ sap & 48.65 & 0.83 & 581.75 & 77.71 & 15.31 & 11.18 & 18.37 & 14.01 \\
\hline $\mathrm{RDF}+7.5 \% \mathrm{~K}$ sap & 49.56 & 0.87 & 589.55 & 78.62 & 15.36 & 11.42 & 18.50 & 14.37 \\
\hline $\mathrm{RDF}+10 \% \mathrm{~K}$ sap & 49.72 & 0.95 & 607.35 & 82.01 & 15.46 & 12.03 & 18.67 & 15.15 \\
\hline $\mathrm{RDF}+2.5 \% \mathrm{G}$ sap & 48.16 & 0.88 & 580.85 & 77.36 & 15.37 & 11.24 & 18.22 & 13.91 \\
\hline $\mathrm{RDF}+5 \% \mathrm{G}$ sap & 48.70 & 0.91 & 584.65 & 78.37 & 15.42 & 11.43 & 18.48 & 14.30 \\
\hline $\mathrm{RDF}+7.5 \%$ G sap & 49.59 & 0.94 & 602.55 & 80.94 & 15.45 & 11.83 & 18.57 & 14.84 \\
\hline $\mathrm{RDF}+10 \%$ G sap & 49.97 & 0.98 & 613.45 & 83.24 & 15.51 & 12.22 & 18.77 & 15.42 \\
\hline RDF+water spray & 42.81 & 0.76 & 559.25 & 72.49 & 14.89 & 10.14 & 18.04 & 12.92 \\
\hline $50 \% \mathrm{RD}+6.25 \% \mathrm{~K}$ sap & 49.61 & 0.88 & 593.45 & 79.27 & 15.43 & 11.58 & 18.32 & 14.37 \\
\hline $\mathrm{SEm} \pm$ & 0.10 & 0.02 & 0.95 & 0.52 & 0.04 & 0.11 & 0.08 & 0.04 \\
\hline $\mathrm{CD}(p=0.05)$ & 0.32 & 0.05 & 2.65 & 1.45 & 0.14 & 0.35 & 0.26 & 0.12 \\
\hline
\end{tabular}


Protein (CP) and Crude Fiber (CF) \% were also found maximum under the $10 \% \mathrm{G}$ sap+RDF (15.51 and $18.77 \%$ ) followed by $10 \% \mathrm{~K}$ sap+RDF (15.46 and $18.67 \%$ ). The minimum $\mathrm{CP}$ and $\mathrm{CF} \%$ were observed in the application of water alone (14.89 and 18.04\%). Data revealed that (Table 1) all the combination of $\mathrm{K}$ sap and $\mathrm{G}$ sap with recommended dose of fertilizer recorded significantly recorded higher CPY and CFY. Further, $10 \% \mathrm{~K}$ sap with RDF and $10 \% \mathrm{G}$ sap with RDF was found superior over 5\% and $7.5 \% \mathrm{~K}$ sap And G sap with recommended dose of fertilizer. The higher CPY and CFY were observed under application of $10 \% \mathrm{~K}$ sap+RDF $(12.03$ and $15.15 \mathrm{q} \mathrm{ha}^{-1}$ ) followed by $10 \% \mathrm{G}$ sap+RDF (12.22 and $\left.15.42 \mathrm{q} \mathrm{ha}^{-1}\right)$. The presence of marine bioactive substances in seaweed extract improves stomata uptake efficiency in treated plants compared to non-treated plants (Mancuso et al., 2006).

\subsection{Effect on yield attributes and yields}

Number of branches shoot ${ }^{-1}$ were recorded at maturity and presented in Table 2. It also increases with the increasing dose of $\mathrm{K}$ sap as well as $\mathrm{G}$ sap. The maximum number of shoots plant ${ }^{-1}$ were observed under application of RDF with $10 \% \mathrm{G}$ sap (11.22) followed by application of $\mathrm{RDF}+10 \% \mathrm{~K}$ sap (11.06), while minimum number of shoots plant ${ }^{-1}$ was recorded under $\mathrm{RDF}+$ water spray (8.65). Yield attributing characters like Number of capsules plant ${ }^{-1}$ and test weight were presented in Table 2. Data revealed that all the combination of $\mathrm{K}$ sap and $\mathrm{G}$ sap with recommended dose of fertilizer recorded significantly higher number of capsules plant ${ }^{-1}$ as well as test weight. Further, $10 \% \mathrm{~K}$ sap with RDF and $10 \% \mathrm{G}$ sap with RDF was found superior over 5\% and 7.5\% K sap And G sap with recommended dose of fertilizer. The maximum number of capsules plant ${ }^{-1}$ and test weight was observed under application of $10 \% \mathrm{G}$ sap+RDF (15.81 and $3.45 \mathrm{~g}$ ) followed by $10 \% \mathrm{~K}$ sap+RDF (15.54 and $3.26 \mathrm{~g})$. While minimum number of capsules plant ${ }^{-1}$ and test weight was observed under application of water alone (10.57 and $2.48 \mathrm{~g}$ ).

\subsection{Seed and stover yields}

Seed yield and stover yield were in different treatments was presented in Table 2. Data revealed that all the combination of $\mathrm{K}$ sap as well as $\mathrm{G}$ sap with recommended dose of fertilizer recorded significantly higher seed yield and stover yield. The maximum seed yield and stover yield were recorded with the application of RDF with $10 \% \mathrm{G}$ sap (4.72 and $62.36 \mathrm{q} \mathrm{ha}^{-1}$ ) followed by application of RDF+10\% K sap (4.55 and 59.92 $\left.\mathrm{ha}^{-1}\right)$. The minimum seed yield and stover yield were recorded under RDF+water spray (3.19 and $46.11 \mathrm{q} \mathrm{ha}^{-1}$ ). Erulan et al. (2009) reported that sea weed extract enhanced the growth parameters such as shoot length, root length, leaf area, fresh weight, dry weight and yield.

\begin{tabular}{|c|c|c|c|c|c|c|}
\hline \multirow[t]{2}{*}{ Treatments } & $\begin{array}{l}\text { Crude fiber } \\
\text { yield }\left(\mathrm{q} \mathrm{ha}^{-1}\right)\end{array}$ & $\begin{array}{c}\text { No. of branches } \\
\text { shoots at seed } \\
\text { harvest }\end{array}$ & $\begin{array}{l}\text { No. of } \\
\text { capsules } \\
\text { plant }^{-1}\end{array}$ & $\begin{array}{c}\text { Test } \\
\text { weight }(\mathrm{g})\end{array}$ & $\begin{array}{l}\text { Seed yield } \\
\left(\mathrm{q} \mathrm{ha} \mathrm{h}^{-1}\right)\end{array}$ & $\begin{array}{l}\text { Stover yield } \\
\qquad\left(\mathrm{q} \mathrm{ha} \mathrm{h}^{-1}\right)\end{array}$ \\
\hline & Mean & Mean & Mean & Mean & Mean & Mean \\
\hline $\mathrm{RDF}+2.5 \% \mathrm{~K}$ sap & 13.65 & 10.07 & 12.81 & 2.95 & 3.59 & 51.80 \\
\hline $\mathrm{RDF}+5 \% \mathrm{~K}$ sap & 14.01 & 10.31 & 12.96 & 3.03 & 4.33 & 56.23 \\
\hline $\mathrm{RDF}+7.5 \% \mathrm{~K}$ sap & 14.37 & 10.6 & 14 & 3.16 & 4.44 & 58.01 \\
\hline $\mathrm{RDF}+10 \% \mathrm{~K}$ sap & 15.15 & 11.06 & 15.54 & 3.26 & 4.55 & 59.92 \\
\hline $\mathrm{RDF}+2.5 \% \mathrm{G}$ sap & 13.91 & 10.44 & 14.2 & 2.96 & 3.66 & 51.72 \\
\hline $\mathrm{RDF}+5 \% \mathrm{G}$ sap & 14.30 & 10.53 & 14.65 & 3.08 & 4.47 & 55.81 \\
\hline $\mathrm{RDF}+7.5 \% \mathrm{G}$ sap & 14.84 & 10.87 & 15.12 & 3.2 & 4.63 & 61.63 \\
\hline $\mathrm{RDF}+10 \% \mathrm{G}$ sap & 15.42 & 11.22 & 15.81 & 3.45 & 4.72 & 62.36 \\
\hline $\mathrm{RDF}+$ water spray & 12.92 & 8.65 & 10.57 & 2.48 & 3.19 & 46.11 \\
\hline $50 \% \mathrm{RD}+6.25 \% \mathrm{~K}$ sap & 14.37 & 10.56 & 13.37 & 3.08 & 4.05 & 51.82 \\
\hline $\mathrm{SEm} \pm$ & 0.04 & 0.002 & 0.15 & 0.003 & 0.52 & 0.92 \\
\hline $\mathrm{CD}(p=0.05)$ & 0.12 & 0.04 & 0.45 & 0.01 & 1.56 & 2.32 \\
\hline
\end{tabular}

\section{Conclusion}

Highest GFY and DMY were recorded with the application of RDF with $10 \% \mathrm{G}$ sap (613.45 and $83.24 \mathrm{q} \mathrm{ha}^{-1}$ ) followed by application of $\mathrm{RDF}+10 \% \mathrm{~K}$ sap (607.35 and $\left.82.01 \mathrm{q} \mathrm{ha}^{-1}\right)$, similarly the maximum seed yield and stover yield were recorded with the application of RDF with $10 \% \mathrm{G}$ sap (4.72 and 62.36 $\mathrm{q} \mathrm{ha}^{-1}$ ) followed by application of RDF+10\% K sap (4.07 and $\left.60.59 \mathrm{q} \mathrm{ha}^{-1}\right)$, respectively due to presence of growth promoting hormones (Auxins, Cytokinins, Gibberellins), trace elements, vitamins, amino acids, antibiotics and micronutrients in these saps. 


\section{References}

Craigie, J.S., 2011. Seaweed extracts stimuli in plant science and agriculture. Journal of Applied Phycology 23, 371-393.

Erulan, V., Soundarapandian, P., Thirumaran, G., Ananthan, 2009. Studies on the effect of Sargassum polycystum extract on the growth and biochemical composition of Cajanus cajan (L) mil sp. American-Eurasian Journal of Agricultural and Environmental Sciences 6(4), 392-399.

Gandhiyappan, K., Perumal, P., 2001. Growth promoting effect of seaweed liquid fertilizer (Enteromorpha intestinalis) on the sesame crop plant. Seaweed Research and Utilization 23, 23-25.

Hong, D.D., Hien, H.M., Son, P.N., 2007. Seaweeds from Vietnam used for functional food, medicine and biofertilizer. Journal of Applied Phycology 19, 817-826.

Jayaraj, J., Wan, A., Rahman, M., Punja, Z.K., 2008. Seaweed extracts reduces foliar fungal disease on carrot. Crop Protection 27, 1360-1366.

Kocira, A., Kornas, R., Kocira, S., 2013. Effect assessment of Kelpak sl on the Bean yield. Journal of Central European Agriculture 14(2), 67-76.
Kumari, R., Kaur, I., Bhatnagar, A.K., 2011. Effect of aqueous extract of Sargassum johnstonii Setchel and Gardner on growth, yield and quality of Lycopersicon esculentum Mill. Journal of Applied Phycology 23, 623-633.

Mancuso, S., Azzarello, E., Mugnai, S., Briand, X., 2006. Marine bioactive substances (IPA extract) improve foliar ion uptake and water tolerance in potted Vitis vinifera plants. Advances in Horticultural Science 20, 156-161.

Rathore, S., 2009. Effect of seaweed extract on the growth, yield and nutrient uptake of soybean (Glycine max) under rainfed conditions, South African Journal of Botany 75, 351-355.

Sivasangari, R., Nagaraj, S., Vijayanand, N., 2011. Influence of Seaweed Liquid Extracts on Growth, Biochemical and Yield Characteristics of Cyamopsis tetragonolaba (L.) Taub. Journal of Phytology 3(9), 37-41.

Sivasankari, S., 2006. Effect of seaweed extracts on the growth and biochemical constituents of Vigna sinensis, Bioresource Technology 97, 1745-1751.

Zhang, X., Ervin, E.H., 2008. Impact of seaweed extract-based cytokinins and zeatin riboside on creeping bentgrass heat tolerance. Crop Science 48, 364-370. 